\title{
DETECTION OF POLYCYCLIC AROMATIC HYDROCARBONS COMPOUNDS CONCENTRATIONS AND THEIR FATE IN TIGRIS RIVER WITHIN BAGHDAD CITY - IRAQ. \\ S. M. Khalaf ${ }^{1}$ \\ Researcher \\ F. M. Hassan ${ }^{1}$ \\ Prof. \\ A. H. J. Al-Obaidy ${ }^{2}$ \\ Prof.
}

${ }^{1}$ Dept.of Biol., Coll. of Science for Women, Univ. of Baghdad, Baghdad, Iraq

${ }^{2}$ Environmental Research Center, Univ. of Techn., Baghdad, Iraq fikrat@csw.uobaghdad.edu.iq

\section{ABSTRACT}

The objective of this study was to investigate concentrations, compositions of PAHs and to study physical and chemical water characteristic in Tigris River. This study was conducted during July 2017 to April 2018. The results showed that twelve PAHs compounds were detected in water and sediment of the river and the highest concentrations of these compounds were founded in sediment samples. Concentrations of PAHs in water samples have a ranged between $\left(0.36 \mu \mathrm{g} . \mathrm{I}^{-1}\right)$ in wet season to $\left(0.53 \mu \mathrm{g} . \mathrm{I}^{-1}\right)$ in dry season, while the sediment sample have a ranged between $\left(633.23 \mu \mathrm{g} . \mathrm{kg}^{-1}\right)$ in wet season to $\left(778.28 \mu \mathrm{g} \cdot \mathrm{kg}^{-1}\right)$ in dry season. The origin of PAHs in water and sediment were pyrogenic depending on the ratios of Phenanthene/Anthracene, Anthacene/ (Anthacene + Phenanthene), low molecular weight/high molecular weight. According of these results, it can be concluded that the Tigris River is polluted with the PAHs, and anthropogenic activities with the largest impact on the water health and quality of the river.

Keywords: lotic system, PAHs compounds, pollutant, water pollution.

*Part of M.Sc. thesis of $1^{\text {st }}$ author.

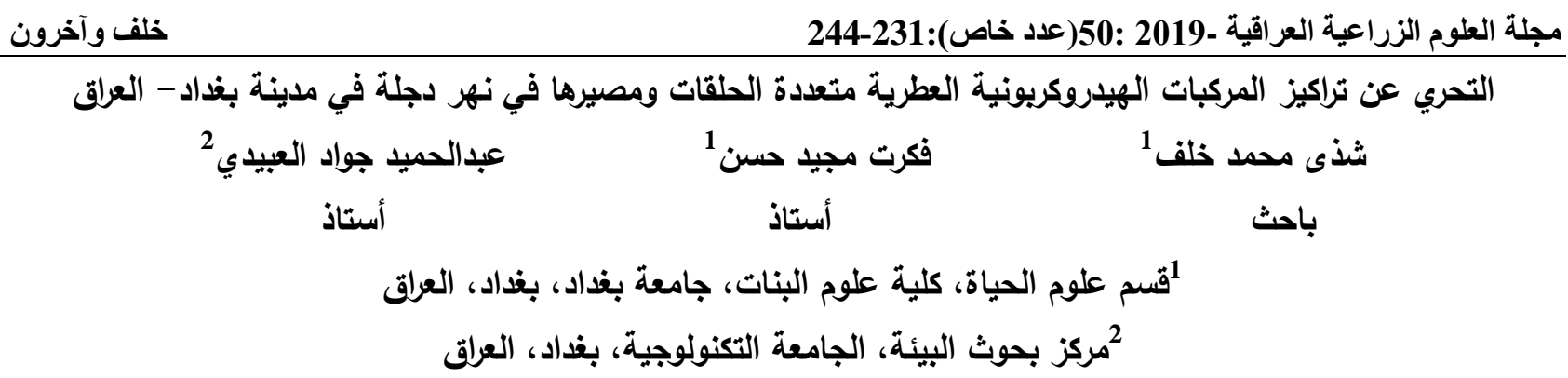

المستخلص

الهـف من هذه الدراسة للكثف عن تراكيب ومكونات متعددة الحلقات ودراسة الصفات الفيزيائية والكيميائية لمياه نهر دجلة خلال الفترة من (تموز2017 إلى أبريل2018). بينت نتائج الدراسة عن وجود اثناعشرمركب هيدركريوني في عينات الماء

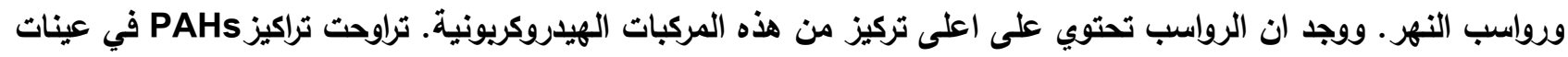
الماء بين 0.36 مايكروغرام/لتز في الفصل الرطب و0.53 مايكروغرام/لتر في الفصل الجاف، بينما كانت تراكيزهذه المركبات في عينات الرواسب بين (633.23 مايكروغرام/كفم) في الفصل الرطب الى (28. 778 مايكروغرام/كفم) في الفصل الجاف. اصل المركبات الهيدوجينية (PAHs) في مياه ورواسب النهر يعتمد على نسب المركبات الهيدركربونية Phenanthene/Anthacene, Anthacenet/(Anthacene + Phenanthene), low molecular weight ) PAHs (/high molecular weight ورواسب نهر دجلة ضمن مدينة بغداد ملوثة بالمركبات الهيدركريونية، وان النشاطات الصناعية لها تأثير كبير في صحة ونوعية مياه النهر . الكلمات المفتاحية: مياه جارية، المركبات الهيدروكريونية،الملوثات،تلوث المياه. جزء من رسالة ماجستير للباحث الاول. 


\section{INTRODUCTION}

The main Iraqi resources (Tigris and Euphrates) were suffered from the decline of their annual flow, many factors impact of this situation such as dam construction in neighboring countries and the impact of global climate change $(4,6)$. The maximum discharge of the Tigris River before the construction of dams for the period 1931-1960 reached $1.207 \mathrm{~m} 3 / \mathrm{s}$. While its discharge declining to $927 \mathrm{~m}^{3} \cdot \mathrm{s}^{-1} \quad(1960-2000)$ after construction of dams. In 1980 the annual river flow reached $715 \mathrm{~m}_{3} / \mathrm{s}$. This decline was continuing and fell to522 $\mathrm{m}_{3} / \mathrm{s}^{-1}$ at Baghdad city after 2000 (5). Both of increase the temperature, reducing precipitation, and also increase of water scarcity important elements of climate changes increase of temperature, reducing precipitation, and also increase of water scarcity. That's effect of decrease sizes of lakes, drying wetlands, and changing regional environment (1). River monitoring is essential to identify changes in the physical and chemical properties of water, which are considered as indicators of pollution. There are different groups of pollutants, one of them is polycyclic aromatic hydrocarbons (PAHs), that have two or more fused rings from big group of organic pollutants. The occurrence of PAHs detected and distributed in both aquatic and terrestrial environment, and both of low solubility and hydrophobic nature PAHs are most found bind to soil and sediment (73). The PAHs in aquatic environment were originate from two sources the first one was pyrogenic which are produced from incomplete combustion of coal, oil, and gas, garbage, or other organic substances like tobacco or charbroiled meat $(32,34,58)$. The second origin was petrogenic which produced from anthropogenic sources that are from the accidental leak out of fossil fuels include crude oil refinery oil (e.g. petrol) (28). PAHs origin can be evaluated from different indices like ratio of Phenanthrene/ Anthracene, Benzo[a] anthracene/(Chrysene+Benzo[a]anthracene),Fl uoranthene/ (Fluoranthene+ Pyrene), and low molecular weight/high molecular weight (67). The origin of PAHs for both water and sediments are pyrogenic origin, according to the results of the ratios (P/Ant $>10$, Ant/(Ant + P) $<0.1$ and (LMW/HMW) $>1$, while the results of $\mathrm{P} / \mathrm{Ant}<10$, Ant/(Ant $+\mathrm{P})>0.1$, (LMW/HMW) $<1 \quad$ were indicated to petrogenic origin $(65,69,78)$. In the beginning of $20^{\text {th }}$ century PAHs carcinogenicity was demonstrated, when exposing mice and rabbits to PAH-containing material it cause tumer. In humans, number of epidemiological studies have demonstrated that exposure to environmental PAHs was associated with elevated cancer in organs of human body (35). Seven compounds of PAHs were classified as human carcinogens included: Benzo[a] anthracene,benzo[a]pyrene,benzo[b]fluoranthe ne,benzo[k]fluoranthene,chrysene,dibenzo[ah] anthracene,indeno[1,2,3-cd] pyrene, because of mutagenic and carcinogenic properties of PAHs, so they have been measured in different environmental matrices like air, water, particulate, plant, sediment (29). The fate and behavior of PAHs when entering aquatic ecosystem were depending on the physicochemical properties, volatilization, dissolution, adsorption on to suspended solids and subsequent sediments (23). The important reservoir of PAHs in the aquatic environment was sediment, due to the accumulation of PAHs in it, when they are associated with particulate fraction via diffusion and sorption (75). The main two sources of PAHs inputs into the aquatic environment are water movement that contains dissolved and particulate constituents derived from watersheds, and atmospheric deposition both in precipitation and dry deposition from air sheds of the coastal ocean (82). The objectives of current study were to investigate concentrations and compositions of PAHs and to elucidate their potential sources, also study physical and chemical parameters of water in Tigris River water within Baghdad city and their correlation with PAHs, lastly to evaluate the possible carcinogenic risk of PAHs in Tigris River water.

\section{MATERIALS AND METHODS \\ Sampling area}

Three sites along Tigris River were selected in order to estimate concentrations of PAHs. Site 1 (Alkreaat) was located upstream, while site 2(Jadriya) was situated in the midstream and the site 3(General company of vegetable oil/Rasheed plant) was located at the downstream as show in Table 1, Figure1, 
according to global positions system (GPS) locations.

\section{Water samples}

Samples of water were collected from depth of $50 \mathrm{~cm}$ by pre-cleaned dark glass bottle (11) in a metallic holder around the bottle connected with a rope that was lowered into the water and allows to rest briefly to ensure that it is filled with water and then transferred to the labeled dark bottle (with volume 2.5 l) containing $60 \mathrm{ml}$ of carbon tetra chloride $\mathrm{CCl}_{4}$ solvent. Sediment was collected by using Ekman grab sampler and stored frozen at -20 ${ }^{\circ} \mathrm{C}$ before analyzing (38).

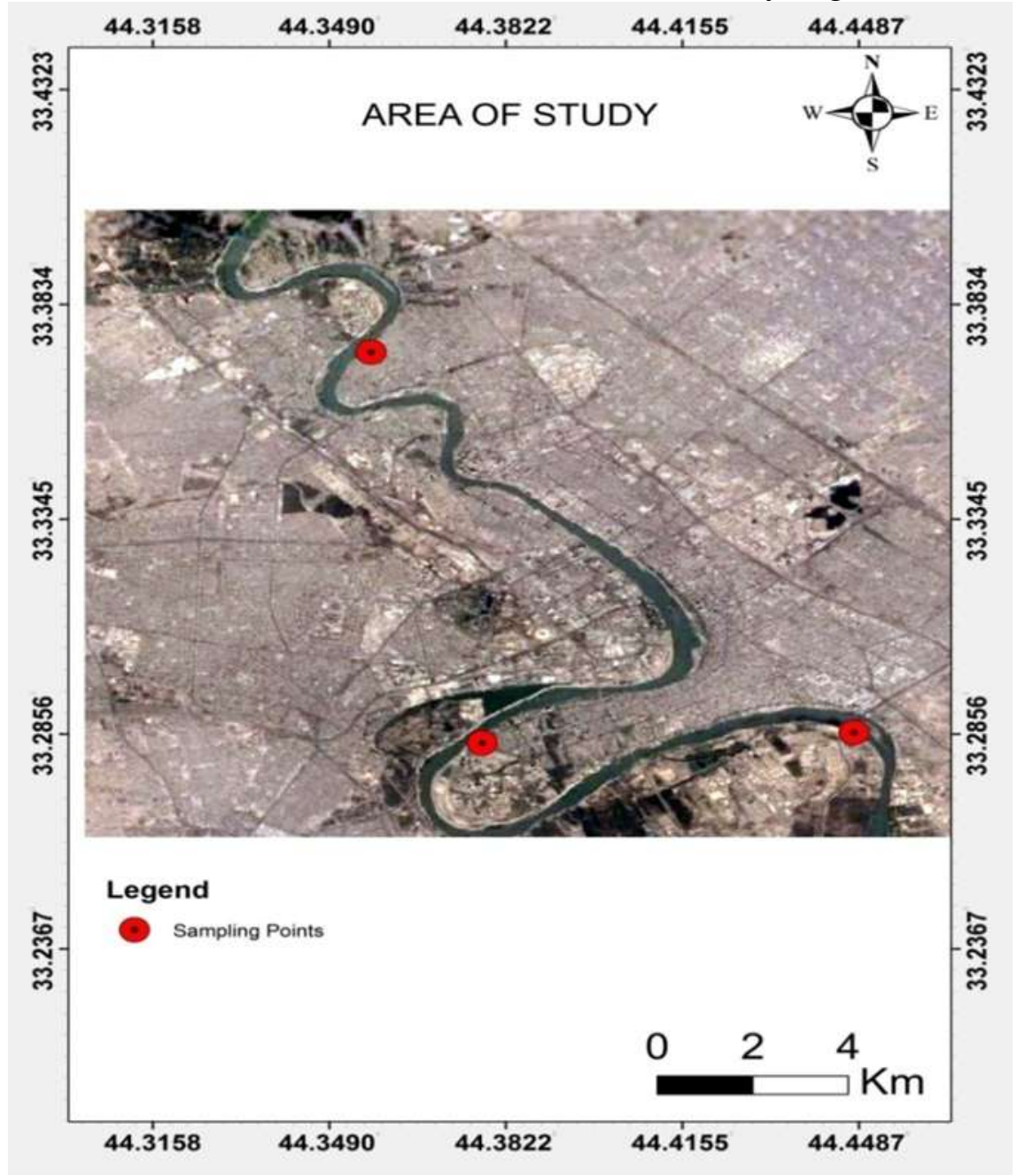

Fig. 1. Map of the study sites

Table1. Geographical positioning system (GPS) of the selected sites

\begin{tabular}{|c|c|c|c|c|c|c|c|c|}
\hline sites & $\begin{array}{l}\text { The } \\
\text { catchment } \\
\text { area }\end{array}$ & $\begin{array}{l}\text { Longitude } \\
\text { (eastwards) }\end{array}$ & $\begin{array}{l}\text { Latitude(north } \\
\text { wards) }\end{array}$ & $\begin{array}{l}\text { Activities of } \\
\text { catchment } \\
\text { area }\end{array}$ & TOC\% & Sand \% & Silt\% & Clay\% \\
\hline S1 & Kreaat & $" 20.28 ' 44^{\circ} 20$ & "12.36'33인 & Agriculture & 12.57 & $33 \%$ & $37 \%$ & $30 \%$ \\
\hline S2 & Jaderiya & "30.42'44 22 & $" 12.62 ' 33^{\circ} 21$ & Urban & 11.81 & 7\% & $53 \%$ & $40 \%$ \\
\hline S3 & $\begin{array}{l}\text { Rasheed } \\
\text { plant }\end{array}$ & "48.20'44 $44^{\circ}$ & "'10.78'33'17 & industrial & 8.88 & $16 \%$ & $49 \%$ & $35 \%$ \\
\hline
\end{tabular}

\section{PAHs analysis}

A $30 \mathrm{ml} \mathrm{CCl}_{4}$ was added to each one liter of sample in separator funnel, then shaken for one hour, to separate organic layer, the settled organic layer was collected in tight glass container and dark. Extraction procedure was repeated with another $60 \mathrm{ml}$ of $\mathrm{CCl}_{4}$ and collected in the same container. Then by rotary evaporator organic extract was evaporated.
Sediment was dried under $15^{\circ} \mathrm{C}$. A dry weight of sample $(10 \mathrm{~g})$ was homogenized in a stainless steel container, and then mixed with $25 \mathrm{ml}$ of acetone with handle for $5 \mathrm{~min}$, soak in a dark-cold place over night. This mixture was shaken for $1 \mathrm{~h}$. The solution was separated in dark glass containers and this process was repeated three times. Then the solution centrifuged at2.500 $\mathrm{rpm}$ for $5 \mathrm{~min}$. The 
supernatant solution was transferred for separation processes with a mixture of $50 \mathrm{ml}$ hexane and $100 \mathrm{ml}$ deionized water. The final volume of separation solution reduced to 10 $\mathrm{ml}$ by rotary evaporator (74). Extraction of PAHs from water, and sediment were analyzed by Gas Chromatography (Schimadzu, 2010, Japan) (column oven $(\mathrm{SE}-30 \mathrm{~m})=150{ }^{\circ} \mathrm{C}$ (hold 1 min. $)-290{ }^{\circ} \mathrm{C}\left(10{ }^{\circ} \mathrm{C} / \mathrm{min}\right)$ temperature of injector $=280{ }^{\circ} \mathrm{C}$, temperature of detector $(\mathrm{FID})=310{ }^{\circ} \mathrm{C}$, pressure100KPa, injection volume $=1 \mathrm{u}$ 1) (26).

\section{Physical and chemical properties}

The samples were collected during two seasons dry season include the months (July, August, September, October, and November) and wet season include the months (December, January, February, March, and April) 20172018. Air and water temperatures, turbidity, transparency, salinity, total dissolved solid (TDS), total suspended solid (TSS), Electrical conductivity, $\mathrm{pH}$, alkalinity, total hardness, calcium, magnesium, chloride, sulfate, phosphate, dissolved oxygen (DO), and biological oxygen demand $\left(\mathrm{BOD}_{5}\right)$ were measured according APHA(American Public Health Association) (71). Total organic carbon (TOC\%) was analyzed following method described in Gaudette et al. (33). The texture of sediment was analyzed in the manner described by Salman et al.(74). Water flow was analyzed according to Maulood et al. (55). The present study results were analyzed statistically by Tibco Statistica (version 13.3and Conoco for windows 4.5 CCA (canonical correspondence analysis).

\section{RESULTS AND DISCUSSION}

Table 2 shows the comparison between the physical and chemical parameters of the studied area with both of the Iraqi Standards (law25/1967) and CCME (24, 45).

\section{Electrical conductivity (EC)}

The monthly variations of EC between August to November 2017 were ranged from $803 \mu \mathrm{s} . \mathrm{cm}^{-1}$ to $1205.67 \mu \mathrm{s} . \mathrm{cm}^{-1}$ in. The mean value was $963.70 \mu \mathrm{s} . \mathrm{cm}^{-1}$, this value is within recommended limit of IS. Spatial variation of EC was varying between $929.7 \mu \mathrm{cm} . \mathrm{cm}^{-1}$ at S2 and $997.2 \mu \mathrm{cm} . \mathrm{cm}^{-1}$ at $\mathrm{S} 1$. Electrical conductivity (EC) is a measure of the ease with which electrical current can pass through water. It can be measured accurately in the field using a poor table conductivity probe and meter (63). The results of EC showed that there is increased in dry season compared to wet season, that might be due to increase the temperature in dry season, which cause raising in EC values, that's agreed with results reported by Hassan et al (41) and Talib et al.(77), in addition to decreased river water levels in these months, there were no clear differences between sites

\section{Salinity (S\%)}

The results showed that the minimum value of S\%o was recorded $0.33 \%$ in August, October2017 and April 2018, and the maximum value was $0.57 \%$ in November 2017 , with mean value $0.42 \%$. Spatial variation of salinity ranged from $0.41 \%$ at $\mathrm{S} 2$ to $0.43 \%$ at S1and S3. The increasing value of salinity in dry season was due to the Lake Tharthar is affected on increasing salinity of Tigris River water When water levels of the River were decreasing, then water has been added from Lake, which characterized with high salinity (70), and from drainage of lands around the river (81), there is no variations between sites just a bit (80). Tigris River water is fresh water according to the classification of water river salinity by Mayer et al (57).

\section{Air temperature (Ta) and water temperature ( $\mathrm{Tw}$ )}

The results showed that the Ta variation between February2018 and July 2017 were ranged to $13.17^{\circ} \mathrm{C}$ and $41^{\circ} \mathrm{C}$, with mean value $25.43^{\circ} \mathrm{C}$. The minimum of Ta value $\left(21.68^{\circ} \mathrm{C}\right)$ recorded at $\mathrm{S} 2$ and the maximum value was $26.59{ }^{\circ} \mathrm{C}$ at S3. The fluctuation in river water temperature (Tw) usually depends on the season, geographic location, sampling time and temperature of effluents entering the stream (2). Water temperature varied between $12.87 \mathrm{C}^{\circ}$ in July 2017 and $30.20^{\circ} \mathrm{C}$ in February, 2018 with mean value $20.55{ }^{\circ} \mathrm{C}$, the mean value Tw was higher than CCME Table 3. Spatial variations ranged from $20.22^{\circ} \mathrm{C}$ at $\mathrm{S} 2$ to $20.83^{\circ} \mathrm{C}$ at $\mathrm{S} 3$. Variations in $\mathrm{Ta}$, Tw between seasons are well known in Iraqi climate that it's characterized by the hot desert climate $(39,42)$.

\section{Total dissolved solids (TDS)}

TDS represented all inorganic salts, organic material and other soluble material in water. These constituted may be found naturally or 
due to discharge of municipal, industrial and agricultural, so its values followed the trend as conductivity and salinity (41). The values of TDS ranged from436.67 mg. $\mathrm{l}^{-1}$ to634.33 mg. $\mathrm{l}^{-1}$, in august 2017 to November and December 2017 with mean value $528.33 \mathrm{mg} . \mathrm{l}^{-1}$. TDS mean value exceed permissible IS Table 3. Spatial variation of TDS ranged from502.7mg. $1^{-1}$ at $\mathrm{S} 2$ to $550.7 \mathrm{mg} . \mathrm{l}^{-1}$ at $\mathrm{S} 1$.

\section{Transparency (Trans)}

Trans were ranged from $12 \mathrm{~cm}$ in April to $75.33 \mathrm{~cm}$ in February 2018 with the mean value $58.60 \mathrm{~cm}$. Spatial variation of Trans values varied between $51.4 \mathrm{~cm}$ at $\mathrm{S} 1$ and $65.6 \mathrm{~cm}$ at $\mathrm{S} 2$. The spatial and temporal variations returned to water flow and turbidity (34). This result was similar to study reported by Hassan et al (40).

\section{Total suspended solids (TSS)}

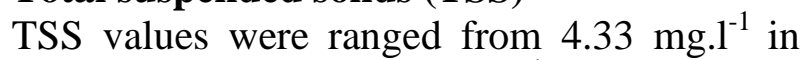
February 2018 to 70.67 mg..$^{-1}$ in April 2018 with mean value $19.33 \mathrm{mg}^{-1} \mathrm{l}^{-1}$. Spatial variation of TSS was ranged between $17.05 \mathrm{mg} .1^{-1}$ at S1 to $21.4 \mathrm{mg} . \mathrm{l}^{-1}$ at $\mathrm{S} 3$ Temporal and spatial variations of TSS return to water flow, and the discharge (22). TSS values were affected by many factors in river water such as silting, microscopic organisms and suspended organic matter lead to catch the dust and other materials not drawn into the water column and eventually deposited on the $(60,21)$. These results were similar to the study of Hassan et al (41).

\section{Turbidity (TUR)}

The results of turbidity values were ranged from12.87 NTU in October, 2017 to 62.87 NTU in April 2018 with mean value reached to 27.59 NTU. Spatial variation of TUR ranged from24.106 NTU at S2 to30.425 NTU at $\mathrm{S} 1$ The reason for the increase in the turbidity of water in the Tigris River may be due to the entry of large amounts of materials that are constantly connected to the river, especially during the rainy season, when the water level of Tigris River increased $(40,60)$. Spatial and temporal values were higher than the recommended limit by IS (5NTU) for both seasons, that's due to water flow (62). These results agreed with another studies (21, 43, 72).

\section{Water flow (WF)}

The water flow was ranged from $0.03 \mathrm{~m} . \mathrm{s}^{-1}$ in September 2017 to $0.18 \mathrm{~m} . \mathrm{s}^{-1}$ in April 2018 with mean value $0.10 \mathrm{~m} . \mathrm{s}^{-1}$. Spatial variation of WF was ranging from $0.08 \mathrm{~m} . \mathrm{s}^{-1}$ at $\mathrm{S} 1$ to $0.11 \mathrm{~m} . \mathrm{s}^{-1}$ at $\mathrm{S} 2$. The variations in months were due to rain and snow melt, while spatial variations were caused by geomorphologic of sites, site 1 there is small island in middle of river, that's might be decreased WF, while site 2 there is meander in river path (46).

\section{Alkalinity (ALK)}

Alkalinity values were ranged from $150 \mathrm{mg} . \mathrm{l}^{-1}$ in July 2017 to $373.33 \mathrm{mg}^{-1}{ }^{-1}$ in September 2017 with mean $246.13 \mathrm{mg} . \mathrm{l}^{-1}$. The average of spatial variation of ALK ranged from $218.3 \mathrm{mg} .1^{-1}$ at $\mathrm{S} 2$ to $270.5 \mathrm{mg} .1^{-1}$ at $\mathrm{S} 1$. Iraqi waters is characterized as alkaline, according to current results of alkalinity, Tigris River water has alkaline properties, this due to presence bicarbonate and carbonate ions in river water (72). Many previous study agrees with this finding $(10,19,41,44)$. The results of high alkalinity in study period and sites can be attributed to natural explanations, such as the influence of geology and soil in the area, and will consequently vary naturally. If the water passes through soil and rock containing carbonate minerals, such as calcite $(\mathrm{CaCO} 3)$, then $\mathrm{CO}_{3}{ }^{-2}$ and $\mathrm{HCO}_{3}{ }^{-}$will be added to the water (19).

\section{Biological oxygen demand (BOD)}

The BOD values ranged from $1 \mathrm{mg}^{-l^{-1}}$ in January 2018 to $1.6 \mathrm{mg}^{-1} \mathrm{l}^{-1}$ in July 2017 with

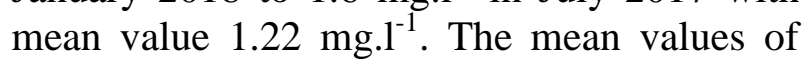
spatial variations of BOD varied between 0.91 mg. $1^{-1}$ at $S 2$ to $1.46 \mathrm{mg}^{-1} \mathrm{l}^{-1}$ at $\mathrm{S} 3$. The real cause of increasing BOD value in dry season is the consuming of organic by bacteria. The temporal and spatial results of BOD clear that there were no anoxia of Tigris River water, and the results were in permissible level recommended by the Iraq, this result agrees with study reported by Amteghy (20).

\section{Calcium $\left(\mathbf{C a}^{+2}\right)$}

The calcium values were ranged from 27.23 mg. $l^{-1}$ in August and September 2017 to $123.59 \mathrm{mg} . \mathrm{l}^{-1}$ in February2018with mean value $74.73 \mathrm{mg} . \mathrm{l}^{-1}$. Calcium mean value was exceed recommended limit of IS (law25/1967). Spatial variation was ranging from $65.36 \mathrm{mg} . \mathrm{l}^{-}$ 1 at S1 to $82.96 \mathrm{mg} . \mathrm{l}^{-1}$ at S2. Mean 
concentrations of $\mathrm{Ca}^{+2}$ were increased in wet season compared with dry season and may be attributed to the high rain fall in this season which dissolve the salts from soil to the river. The increase in $\mathrm{Ca}^{+2}$ spatial values may be due to agriculture land round the site (11). Same results were reported by Al-Janabi (10).

\section{Chloride ions $\left(\mathrm{Cl}^{-}\right)$}

Chloride ions $\mathrm{Cl}^{-}$values were ranged from $23.33 \mathrm{mg} . \mathrm{l}^{-1}$ in October 2017 to119.96 mg. $\mathrm{l}^{-1}$ in April 2018 with mean value $68.15 \mathrm{mg} \cdot \mathrm{l}^{-1}$. Mean value of chloride ion within allowable limit of IS. Spatial variation ranged from 66.98 mg. $\mathrm{l}^{-1}$ in S2 to $68.9785 \mathrm{mg} . \mathrm{l}^{-1}$ in S1. Mean concentrations of $\mathrm{Cl}^{-}$increased in wet season compared with dry season that may be attributed to the high rain fall in this season and lead to dissolve the salts in soil and cross to the river. The raised in spatial variations of $\mathrm{Cl}^{-}$in $\mathrm{S} 1$ might be because of agriculture land round the site (11). These results matched with others studies $(3,9,13)$.

\section{Dissolved oxygen (DO)}

Temporal variations were varying from 5.77 mg. $\mathrm{l}^{-1}$ in July 2017 to $11.75 \mathrm{mg} . \mathrm{l}^{-1}$ in January 2018 with mean value $8.06 \mathrm{mg}^{-\mathrm{l}^{-1}}$. Spatial value ranged from $7.5 \mathrm{mg} .1^{-1} \mathrm{~S} 1$ to $8.43 \mathrm{mg} .1^{-}$ ${ }^{1} \mathrm{~S} 3$.The DO values within allowable limit of IS (law/25) DO considered the critical parameter for distinction the health of an aquatic ecosystem and is usually use as a water quality indicator (51). Seasonal variations of DO were due to affect of temperature on oxygen solubility (48). There was no decrease in dissolved oxygen value at any sites throughout the study period so many factor helps increasing DO in water like; photosynthetic in the system, low temperature, low of salinity and the mixing of atmospheric oxygen with waters through wind and stream current action (80). The present results agreed with other studies $(16,41)$.

Table 2. Physico-chemical values of Tigris River

\begin{tabular}{|c|c|c|c|c|c|c|}
\hline Physical parameters & Minimum & Maximum & Mean & Std. Deviation & I S Law/25 & CCME \\
\hline $\mathrm{EC}\left(\mu\right.$ s.cm $\left.^{-1}\right)$ & 803.0 & 1205.7 & 963.700 & 164.24 & & \\
\hline S\%o & 0.3 & 0.57 & .420 & 0.09 & & \\
\hline $\operatorname{Ta}\left({ }^{\circ} \mathbf{C}\right)$ & 13.2 & 41.0 & 25.427 & 8.70 & & \\
\hline $\operatorname{TDS}\left(\mathrm{mg.l}^{-1}\right)$ & 436.7 & 634.3 & 528.332 & 72.18 & 500 & 500 \\
\hline TRANS( cm) & 12.0 & 75.3 & 58.599 & 18.76 & & \\
\hline TSS(mg.l $\left.{ }^{-1}\right)$ & 4.3 & 70.7 & 19.330 & 20.47 & & \\
\hline TUR( NTU) & 12.9 & 62.9 & 27.593 & 14.83 & 5 & 5 \\
\hline $\left.\mathbf{T} \mathbf{w}^{\left({ }^{\circ}\right.} \mathbf{C}\right)$ & 12.9 & 30.2 & 20.548 & 6.21 & & 15 \\
\hline $\mathbf{W F}\left(\mathbf{m} \cdot \mathrm{s}^{-1}\right)$ & $\mathbf{0 . 0 3}$ & 0.18 & 0.096 & 0.04 & & \\
\hline \multicolumn{7}{|l|}{ Chemical parameters } \\
\hline $\operatorname{Alk}\left(\mathrm{mg} \mathrm{CaCO}_{3} \mathbf{1}^{-1}\right)$ & 150 & 373.33 & 246.13 & 80.03 & & \\
\hline BOD $\left(\mathbf{m g . l}^{-1}\right)$ & 1.0 & 1.6 & 1.22 & 0.21 & $<5$ & \\
\hline $\mathrm{Ca}^{+2}\left(\mathrm{mg.l}^{-1}\right)$ & 27.2 & 123.6 & 74.71 & 30.16 & 75 & \\
\hline $\mathrm{Cl}^{-}\left(\mathrm{mg.l}^{-1}\right)$ & 23.3 & 120.0 & 68.15 & 32.33 & 200 & 250 \\
\hline DO $\left(\right.$ mg.l $\left.^{-1}\right)$ & 5.8 & 11.6 & 8.06 & 1.82 & $>5$ & $5.5-9$ \\
\hline $\operatorname{Mg}^{+2}\left(\mathrm{mg.l}^{-1}\right)$ & 19.3 & 72.6 & 45.02 & 15.65 & $\mathbf{5 0}$ & \\
\hline pH & 7.6 & 8.3 & 7.90 & 0.22 & $6.5-8.5$ & $6.5-9$ \\
\hline $\mathrm{PO}_{4}\left(\mathrm{mg.l}^{-1}\right)$ & .2 & 1.4 & 0.49 & 0.35 & 0.4 & 0.1 \\
\hline $\mathrm{SO}_{4}\left(\mathrm{mg.l}^{-1}\right)$ & 134.7 & 277.3 & 202.12 & $\mathbf{5 7 . 8 0}$ & 200 & \\
\hline TOC\% & 2.7 & 21.1 & 11.09 & 6.95 & & \\
\hline $\mathrm{TH}\left(\mathrm{mg}_{\mathrm{CaCO} 3} \cdot \mathrm{I}^{-1}\right)$ & 225.4 & 480.2 & 343.31 & 87.94 & 500 & \\
\hline
\end{tabular}

\section{Magnesium $\left(\mathrm{Mg}^{+2}\right)$}

Magnesium values ranged from $19.26 \mathrm{mg} . \mathrm{l}^{-1}$ in October 2017 to $72.55 \mathrm{mg}^{-\mathrm{l}^{-1}}$ in December

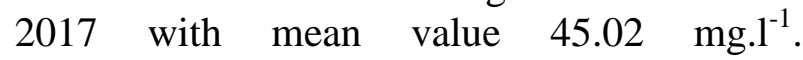
Magnesium mean value was in allowable limit but maximum value exceed permissible limit of IS. The values of spatial variation varied between from $38.33 \mathrm{mg} . \mathrm{l}^{-1}$ at S3 to $57.56 \mathrm{mg} . \mathrm{l}^{-}$ ${ }^{1}$ at $\mathrm{S} 1$. Mean concentrations of $\mathrm{Mg}^{+2}$ increased in wet season compared with dry season may be attributed to the high rain fall in this season which dissolve the salts from soil to the river $(11,17)$. Spatial variations $\mathrm{Mg}$ raised in S1because of agriculture land round the site. $\mathrm{Mg}^{+2}$ present in all natural waters and it was considered as a major contributor to water hardness. Ferromagnesian mineral igneous rocks and magnesium carbonates in sedimentary rocks are generally considered to be the principal sources of magnesium in natural waters (7). This finding matched with other studies $(21,44)$. 
Ph

The $\mathrm{pH}$ values were ranged from 7.60 in November 2017 to 8.27 in July 2017 with mean value 7.89. Mean value within recommended limit. Spatial values ranged from7.65 at $\mathrm{S} 1$ to8.04 at $\mathrm{S} 3, \mathrm{pH}$ regulates most of the biological processes and biochemical reactions. Aquatic $\mathrm{pH}$ ecosystem depends on chemical and biological activity of water (18,54). Natural waters usually have $\mathrm{p} \mathrm{H}$ highest than 7 . The values of $\mathrm{pH}$ in study sites water showed ranging from neutral to slight alkaline. These results similar to other studies $(9,15)$.

\section{Phosphate $\left(\mathrm{PO}_{4}\right)$}

Phosphate concentrations were varying between $0.15 \mathrm{mg} . \mathrm{l}^{-1}$ in March 2018 and 1.39 mg. $1^{-1}$ in February 2018 with mean value 0.49 mg. $1^{-1}$. The maximum and mean values of $\mathrm{PO}_{4}$ were exceed the allowable limit of IS and CCME, as a result of the rainfall that washed away phosphorus compounds to the bodies of water when washing agricultural land enriched with phosphate fertilizers(76) . Spatial variation ranged from $0.28 \mathrm{mg} . \mathrm{l}^{-1}$ at $\mathrm{S} 1$ to 0.65 mg. $1^{-1}$ at S2. The results showed that the concentration of $\mathrm{PO}_{4}$ decreased because of the uptake of $\mathrm{PO}_{4}$ by aquatic plants, and dilution by rain, or discharge (66), therefore the $S 1$ had lowest value of phosphate, because of the large amount of aquatic plants compared to S2. The current results of $\mathrm{PO}_{4}$ were less than the result that recorded by Nashaat (64), and more than the results were recorded by Al-Janabi (9).

\section{Sulfates $\left(\mathrm{SO}_{4}\right)$}

Sulfate concentrations were varying between $134.67 \mathrm{mg} . \mathrm{l}^{-1}$ in October 2017 and 277.33 mg. $1^{-1}$ in November 2017 with mean value $202.12 \mathrm{mg} . \mathrm{l}^{-1}$. Maximum value of $\mathrm{SO}_{4}$ was exceed recommended limit of IS, mean value was almost within permissible limit. Spatial values were ranged from $194.55 \mathrm{mg} . \mathrm{l}^{-1}$ at $\mathrm{S} 1$ to

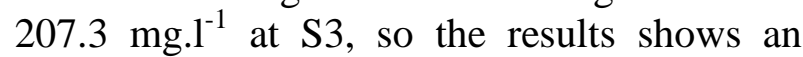
increasing in concentrations of sulfates in wet season compared with dry season. Sulfate concentrations in S1 less than S3, because of industrial buildings round the site (56). These results were matched study reported by Amteghy (20).

\section{Total organic carbon TOC\%}

The percentage of TOC was varying between $2.67 \%$ in April 2018 and 21.14\% in February
2018 with mean value11.09. Spatial variations ranged from $8.88 \%$ at $\mathrm{S} 3$ to $12.57 \%$ at $\mathrm{S} 1$. The variations in results of TOC showed that maximum value might be due to the increasing of river discharge and algal blooms (52).

\section{Total hardness (TH)}

Hardness values were ranged from 225.40 mg. $\mathrm{l}^{-1}$ in January 2018 to $480.20 \mathrm{mg} . \mathrm{l}^{-1}$ in November 2017 with mean value $343.31 \mathrm{mg} . \mathrm{l}^{-}$

1 . Hardness values were within permissible limit of IS. Spatial values ranged from 309.58 mg. $1^{-1}$ at S2 to $401.24 \mathrm{mg} . \mathrm{l}^{-1}$ at S1. Hardness results showed that there is increased in dry season compared to wet season, maximum values for hardness were observed after receiving very hard water from Tharthar Reservoir, these results were agrees with study submitted by Al Lami (14), while the minimum values were due to dilution in the (rainy) wet season (68). Maximum value of $\mathrm{TH}$ at $\mathrm{S} 1$ came from agriculture land around site. According to the results of $\mathrm{TH}$ Tigris River can be classified as very hard water, as criteria illustrated by Lind (49).

Polycyclic aromatic hydrocarbons (PAHs) in water

Descriptive data of PAHs compounds were shown in Table 3 and compare with CCME standards of PAHs in water (24).

The results of this study were revealed that the concentration of total PAHs in water $\mu \mathrm{g} .1^{-1}$ samples was $0.53 \mu \mathrm{g} . \mathrm{l}^{-1}$ in dry season and 0.36 $\mu \mathrm{g} . \mathrm{l}^{-1}$ in wet season. Al-Azawii et al and Hameed et al $(8,27)$ were reported that the minimum value of PAHs in Tigris River in Baghdad city was in summer, these finding disagreed within present results . Zhu et al. (85) found a higher concentration of PAHs in dry season than in wet season that may be contributed to the sorption of PAHs on to the suspended particles and atmospheric deposition which increase during dry season. The concentration of PAHs may be reduced or diluted during periods of highest water flow (28). These findings were agreed with the present study which revealed the high flow of water during wet season, whereas the low levels of flow were recorded during the dry season. In general the concentrations of PAH in water depend on several factors, including, properties of PAHs as hydrophobic nature with low solubility $(23,79)$. The maximum value of 
PAHs compounds in water was7.03 $\mu \mathrm{g} . \mathrm{l}^{-1}$ (Ova) in February 2018, most abundant compound of PAHs was Acy. Mean concentration of PAHs compounds in water sample of Tigris River revealed that LMW compounds lower than HMW in all sampling sites and both in dry and wet seasons. This is due to that the lower molecular weight of PAHs degraded rapidly in sediments, but the higher molecular weight PAHs are more recalcitrant, lower molecular weight of PAHs (1-3 ringed) are usually lost due to microbial degradation and volatilization while larger molecular weight compounds (4-5 ringed) get lost as a result of photo-oxidation and maybe attached to the underlying sediments $(36,53$, 59), so the origin of the PAHs compounds in water was pyrogenic according to the ratios P/Ant, Ant/(Ant+P), LMW/HMW (65 , 69, 78 ,). The results of the present study was revealed that the concentrations of total polycyclic aromatic hydrocarbons in water samples were $(0.31,0.43$, and 0.33$) \mu \mathrm{g} . l^{-1}$ in first, second, and third sites respectively, the concentration of PAHs in site 2 was a highest than S1, and S3, this due to the meander of the river in site 2, and presence of Marsa El Jadriya restaurant, where there is boats and floating restaurant, whears related to urban runoffs, sewage discharges, and intense shipping (25). From the twelve PAHs compounds, there are 4 carcinogenic compounds $\mathrm{B}[\mathrm{a}]$ ant, B[a]fl, Chry, and DHA (30).

Table 3. Descriptive data of PAHs compounds in water

\begin{tabular}{|c|c|c|c|c|c|c|}
\hline variables & Mean & Median & Minimum & Maximum & Std.Dev. & CCME \\
\hline Acy & 0.06 & 0.05 & ND & 0.12 & 0.04 & - \\
\hline Ant & 0.35 & 0.01 & ND & 2.34 & 0.88 & 0.012 \\
\hline B[a]Ant & 0.08 & 0.01 & ND & 0.28 & 0.13 & 0.018 \\
\hline B[a]fl & 0.16 & 0.05 & ND & 0.39 & 0.20 & - \\
\hline Chry & 0.27 & 0.16 & ND & 0.75 & 0.25 & - \\
\hline DHA & 0.11 & 0.11 & ND & 0.17 & 0.09 & - \\
\hline $\mathbf{F}$ & 0.10 & 0.06 & ND & 0.24 & 0.08 & 3 \\
\hline $\mathbf{N}$ & 0.30 & 0.24 & ND & 0.55 & 0.17 & 1.1 \\
\hline Ova & 1.23 & 0.13 & ND & 7.03 & 2.57 & - \\
\hline $\mathbf{P}$ & 0.08 & 0.09 & ND & 0.16 & 0.07 & 0.4 \\
\hline Pyr & 2.44 & 2.66 & ND & 5.30 & 2.41 & 0.025 \\
\hline Tetr & 0.08 & 0.07 & ND & 0.14 & 0.04 & - \\
\hline
\end{tabular}

\section{PAHs in sediment}

The concentrations of PAHs in sediments were shown in Table 4 and compare with CCME standards of PAHs in sediment (24). PAHs mean values in sediments samples were $633.23 \mu \mathrm{g} . \mathrm{kg}^{-1}$ dry weight in wet season $778.28 \mu \mathrm{g} . \mathrm{kg}^{-1}$ dry weight in dry season. AlKhatib, ,Mohammed et al., and Al-Khion $(11,61,12)$ were measured the amount of some PAH compounds in Hor Al- Howaiza, Euphrates River and coastal regions sediment in Iraq, and they showed that the highest levels in winter, while the lowest in summer. Temperature also affects the solubility of hydrocarbons Foght et al. (31), the elevated levels of these compounds during the winter could be attributed to their precipitation, which are significantly be higher in winter than in summer, also the higher energy consumption for heating and increasing the input of PAHs in aquatic environment with run off these compounds during the winter. These results agreeing with present study. Kafilzadeh found that the highest concentrations of PAHs in Sultan Abad River, Iran in water and sediment were in autumn, and lowest in summer (47), that was disagrees with present study. The highest value of PAHs compounds was $4050.44 \mu \mathrm{g} . \mathrm{kg}^{-1}$ of (Chry) in December, and most abundant compounds were Ant, and N. In addition the temperature is lowest in the winter, this will decrease evaporation rate, and causes lower rate of biodegradation Al-Khatib (11). The amount of PAHs in sediments samples were 9914.48, 685.92, and 562.9925) $\mu \mathrm{g} . \mathrm{kg}^{-1}$ (dry weight) at first, second, and third sites respectively, this is probably due to TOC, Liu et al. (50), Xu J (83) agrees with result, which revealed that there is a correlation between TOC and some PAHs compounds. There is a significant negative correlation between some PAHs compounds and the sand in sediment texture (27). The PAHs origin in sediment was pyrogenic at S2 while $\mathrm{S} 1$ and $\mathrm{S} 3$ 
were pyrogenic and petrogenic. The carcinogenic PAHs compounds in sediment represented by $\mathrm{B}[\mathrm{a}]$ Ant, $\mathrm{B}[\mathrm{a}] \mathrm{Fl}$, Chry, and DHA, which exceed limit value in CCME.

Canonical Correlation Analysis (CCA)

In water according to CCA results there was a significant correlation between LMW (Ant), and HMW(Pyr) with BOD, Ta, Tw, $\mathrm{pH}$, and WF, also Tetr with TDS, DO, TH, $\mathrm{Ca}^{+2}, \mathrm{~S} \%$, Trans, EC, $\mathrm{SO}_{4}$, but Ova with $\mathrm{PO}_{4}$, as shown in (Figure 2). In sediment, the results of CCA showed that there is a significant correlation between LMW of PAHs and water parameters, firstly, $\mathrm{N}$ correlated with $\mathrm{ALK}, \mathrm{BOD}, \mathrm{Cl}^{-}$, and TOC. After that $\mathrm{P}$ related with $\mathrm{Tw}$, and $\mathrm{Ta}$, lastly, Ant correlated with DO. HMW correlated with some water parameters, $\mathrm{B}[\mathrm{a}]$ ant, B[a]flu, Pyr, and F correlated with Ta, and $\mathrm{Tw}$, while Tetr related with $\mathrm{pH}$, as shows in Figure 3. From these results, the concentrations of PAHs compounds in sediment were higher than in water at several times, therefore the sediment was considered as a big reservoir of PAHs compounds in river water. Also the indices of the origin of pollution, were estimated the source of PAHs pollution in Tigris River as a pyrogenic. Therefore, the anthropogenic activities of human have high impact on the health and quality of river water

Table 4. Descriptive data of PAHs in sediment

\begin{tabular}{|lllllll|}
\hline variables & Mean & Median & Minimum & Maximum & Std.Dev. & CCME \\
\hline Acy & $\mathbf{9 4 3 . 0 4}$ & $\mathbf{5 2 0 . 4 1}$ & ND & 3716.00 & 1264.77 & 5.87 \\
Ant & 347.05 & 390.88 & ND & 1223.78 & 392.94 & 46.9 \\
B[a]ant & 357.25 & 309.96 & ND & 879.28 & 385.26 & 31.7 \\
B[a]fl & 416.36 & 466.69 & ND & 612.35 & 211.26 & - \\
Chry & 972.08 & 448.43 & ND & 4050.44 & 1337.44 & 57.1 \\
DAH & 1018.41 & 1018.41 & ND & 1065.49 & 66.58 & 6.22 \\
F & 456.73 & 562.44 & ND & 601.34 & 239.12 & 21.2 \\
N & 1354.27 & 1619.69 & ND & 2510.57 & 829.15 & 34.6 \\
Ova & 424.45 & 424.45 & ND & 602.73 & 252.13 & - \\
P & 1500.75 & 1571.65 & ND & 1680.04 & 223.34 & 41.9 \\
Pyr & 118.97 & 118.97 & ND & 217.89 & 139.90 & 53 \\
Tetr & 174.78 & 151.76 & ND & 309.59 & 103.91 & - \\
\hline
\end{tabular}

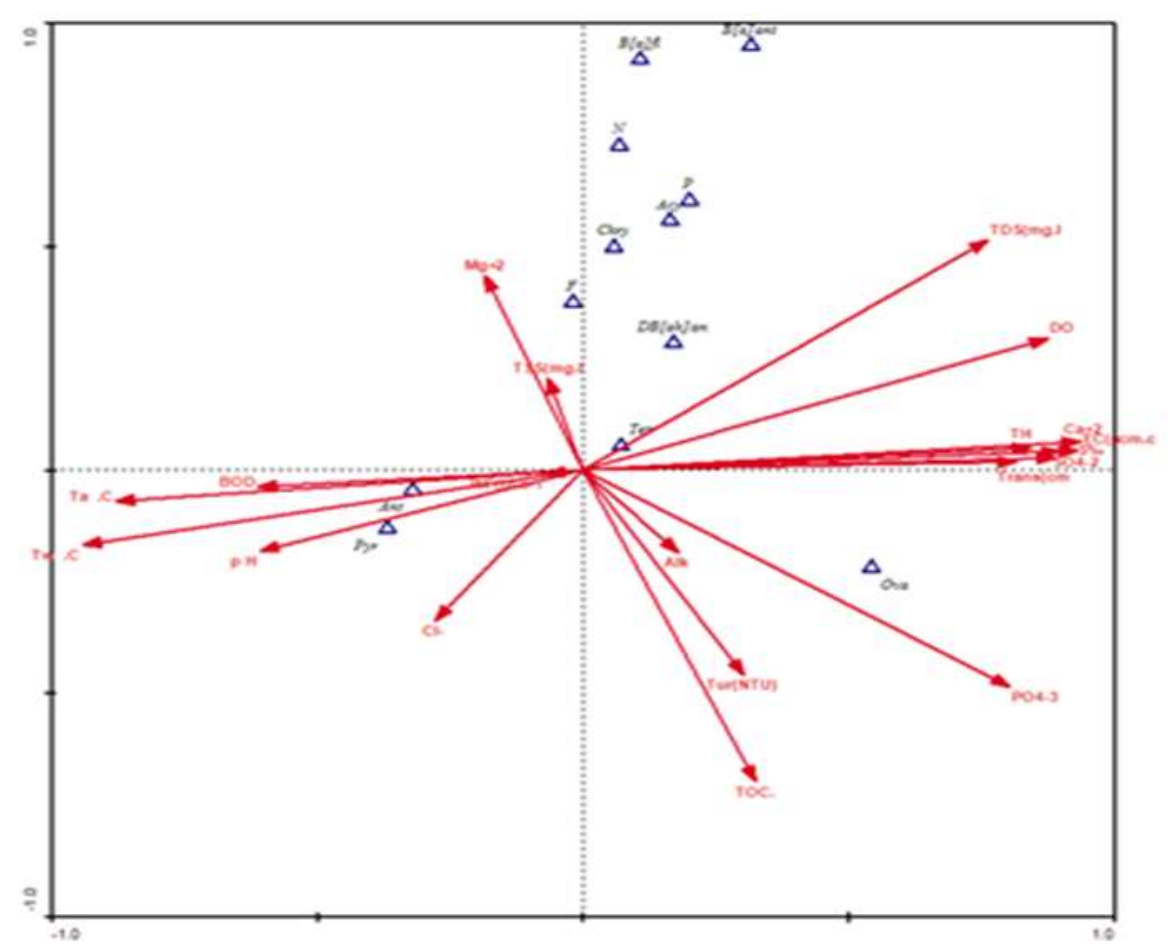

Fig. 2. CCA of PAHs in water and physicochemical parameters of study area 


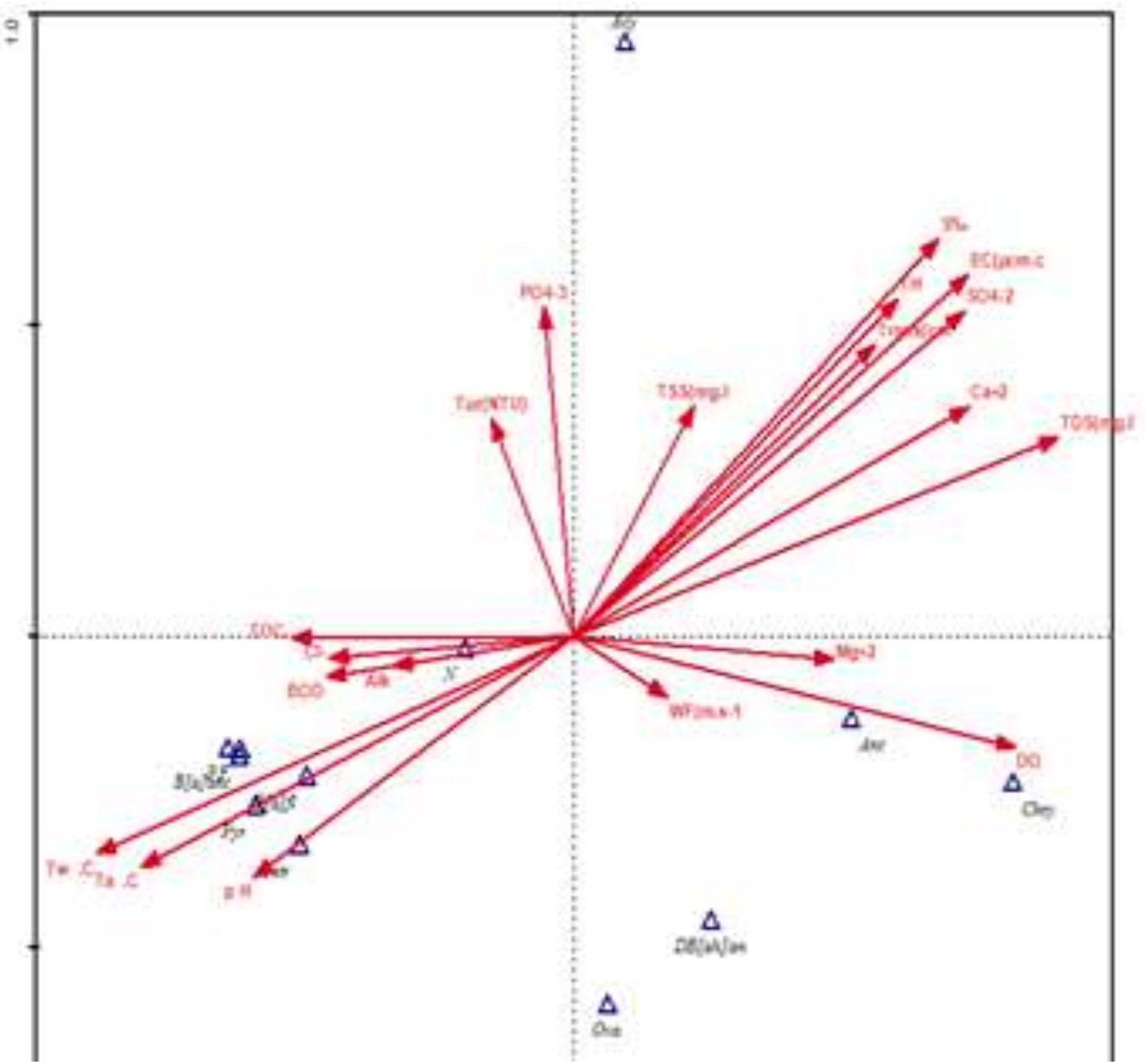

Fig. 3. CCA of PAHs in sediments and

\section{REFERENCES}

1. Adamo N, N Al-ansari, VK Sissakian, and S Knutsson. 2018. Climate change : consequences On Iraq's environment. J of Earth Sci and Geotech Eng. pp: 43-58

2. Ahipathy M.V, and E.T Puttaiah. 2006. Ecological characteristics of Vrishabhavathy River in Bangalore (India). Environ Geol. pp: 1217-1222

3. Al-Ani R.R., A.H.M.J. Obaidy, and R.M. Badri. 2014. Assessment of water quality in the selected sites on the Tigris River, Baghdad-Iraq. Int J Adv Res Journalwww.journalijar.com Int J Adv Res. 2(5):1125-1131.

4. Al-ansari N, M Abdellatif, M Ezeelden, SS Ali, and S Knutsson. 2014. Climate change and future long-term trends of rainfall at Northeast of Iraq. J CivEng Archit. 8(6):790 805

5. Al-Ansari N, N Adamo, V Sissakian, S Knutsson, and J Laue. 2018. Water resources physicochemical parameters of study area of the Euphrates River catchment. J Earth Sci Geotech Eng; 8(3):1-20

6. Al-ansari N, N Adamo1, S Knutsson, and J Laue.2018. Geopolitics of the Tigris and Euphrates basins: J of Earth Sci and Geotech Eng. 8(3):187-222

7. Al'asadi S.H.E.A.2015. Environmental Study of the Algae Community And Some Environmental Pollutants In The Husseiniya River. pH.D. Dissertation, University of Karbala / Iraq. pp:232

8. Al-azawii L.H.A, M.R Nashaat, and M.N Al-azzawi. 2015. Determination of polycyclic aromatic hydrocarbon (PAHs) in the Tigris River through passing Baghdad Province. 56(2):1372-1384

9. Al-Janabi Z. Application of Water Quality Indices for Tigris River within Baghdad CityIraq. 2011. M.Sc. Thesis.pp:160

10. Al-Janabi Z.Z.2012. Assessment of water quality of Tigris River by using water quality index (CCME WQI). J Al-Nahrain Univ. 15(1):119-126 
11. Al-Khatib F.M.H. 2008. Determination the Concentration, Origin and Distribution of Hydrocarbons Compounds in Water, Sediments and some Biota of Hor AlHowaiza, South of Iraq and their sources. Basrah. ph.D. Dissertation, College of Science , University of Basrah, pp:228

12. Al-khion DD. 2012. Distribution Of Polycyclic Nuclear Compounds In Iraqi Coast Regions. College of Agriculture, University of Basrah.M.Sc.Thesis, pp:171.

13. Al-Lami A.A, H.A Al-Saadi, and M.A Jafer. 2000. On the algal composition of AlAdaim River and its effect on Tigris River. $1^{\text {st }}$ National Science of Environmental Pollution and Means Protocol, Baghdad. pp: 38-45

14. Al-Lami AA-Z, Qassem TI, al-DulaimiA A. 2000. A Limnological Study On Tigris River, Iraq. Scie J Iraqi At Energy Comm.;pp:83-98

15. Al-Lami AA-Z. 2002. Water quality and sediments of the Tigris River before and after the Baghdad - Iraq (In Arabic). Iraqi J Biol.; pp:289-296

16. Al-Obaidy A.H. M. J, Z.Z Al-Janabi, and E. Shakir. 2015. Assessment of water quality of Tigris River within Baghdad City. J Mesopotamia Env Mesop Environ J 1(3):90 98

17. Al-Saadi H.A, A.A Al-Lami; T.I and Kassim, H.H Al-Jaberi. 1999. Heavy Metals in Qadisia Lake and its Aquatic Plants. J. College Educ. For Women, University of Baghdad. J Coll Educ Women, Univ Baghdad. pp:281292

18. Al-Saadi H.A; A.A Al-Lami , M.A Jafer. 2000.Limnological Char- acters of Al-Adiam River and their Effects on Tigris River-Iraq. Environ Monit Assess.pp:46-56.

19. Al-saady Y.I., and E.J Abdullah. 2014. Water quality of Tigris River within Missan Governorate eastern part of the mesopotamia plain - Iraq. 9(22):2489-2502

20. Amteghy A.H. 2014. Impact of sewerage water of the water quality of Tigris River in Maysan Province and their possible health risks and removal by using granula activated carbon and sand. Med J Babylon. 11(1):18-36 21. Ayoade A.A, N.K Agarwal, and A.C Chandola-Saklani. 2009. Changes in physicochemical features and plankton of two regulated high altitude rivers Garhwal Himalaya, India. Eur J Sci Res .27(1):77-92

22. Bilotta G.S, and R.E Brazier. 2008. Understanding the influence of suspended solids on water quality and aquatic biota. 42:2849-2861

23. Brooks KM. 1995. Literature Review, Computer Model And Assessment Of The Potential Environmental Risks Associated With Creosote Treated Wood Products Used In Aquatic Environments. West Wood Preserv Inst.pp:143

24. Canadian Council of Ministers of the Environment/Sediment Quality Guide Lines For The Protection Of Aquatic Life. 2007. pp: 1-9

25. Celino JJ., HX Corseuil; M Fernandes; KS Garcia, GM Sánchez, and PSE Silva Júnior da. 2010. Occurrence and Distribution Of Polycyclic Aromatic Hydrocarbons In Surface Water of Todos Os Santos Bay, Bahia, Brazil.pp:40-46.

26. Chrom academy. Theory and Instrumentation of GC Sample Introduction. 2010. Crawford Sci .x;pp:1-39

27. Dahle S, V M Savinova, G G Matishovb. A Evenset, and K Næsc. 2003.Polycyclic aromatic hydrocarbons (PAHs) in bottom sediments of the Kara Sea shelf, Gulf of $\mathrm{Ob}$ and Yenisei Bay. Sci Total Environ.306:57-71 28. Doong R.A, and Y.T Lin. 2004. Characterization and Distribution of Polycyclic Aromatic Hydrocarbon Contaminations In Surface Sediment And Water from Gao-ping River, Taiwan. Water Res.pp: 1733-1744

29. Douben P.E.T. 2003. PAHs: An Ecotoxicological Perspective. John Wiley and Sons, pp:471.

30. EPA. 2010. Polycyclic Aromatic Hydrocarbons ( PAHs ) Factsheet. JRC Tech Notes.104(11) pp:1-25

31. Foght JM, DW Westlake, WM Johnson, and HF Ridgway. 1996. Environmental gasoline-utilizing isolates and clinical isolates of Pseudomonas aeruginosa are taxonomically indistinguishable by chernotaxonornic and molecular techniques;pp: 2333-2340.

32. Garban B, H Blanchoud, A Motelaymassei, M Chevreuil, and D Ollivon. 2002. Atmospheric bulk deposition of PAHs onto 
France: trends from urban to remote sites.J Atmospheric Environment 36:5395-5403.

33. Gaudette HE, WR Flight, L Toner, and DW Folger. 1974. An inexpensive titration method for the determination of organic carbon in recent sediments. J Sediment Petrol.x; 44(1) pp:249-253

34. Green L, K Addy, and N Sanbe. 2014. Measuring Water Clarity. Natural Resources Facts.pp:1-5.

35. Guo Y, K Wu, X Huo, and X Xu. 2011. Sources, distribution, and toxicity of polycyclic aromatic hydrocarbons. J Environ Health. pp:22-25

36. Hameed M.S, F.S Al-zubaidi, and A.S.A Wahab. 2014. Determination of some aromatic hydrocarbon in water of Tigris River near AlDora refinery.55(4):1528-1534.

37. Hamid TA-S, S TA Ali, S Mahdi, B Y. AlKafaji, and AA Al-Hello. 2016. Polycyclic Aromatic Hydrocarbons (PAHs) in Sediment Samples from Euphrates River, Iraq. Int J Mar Sci.pp:1-6

38. Hassan F M, J M Salman, ASN AlAzawey, N Al-Ansari, and S Kutsson. 2014. Quality, quantity and origin of PAHs (Polycyclic Aromatic Hydrocarbons) in lotic ecosystem of Al-Hilla River, Iraq. J Civ Eng Archit. 8(8):1026-1038

39. Hassan FM, DW K Al-Jibouri, and AA Hakman. 2017. Water quality assessment of Diyala river in Diyala province, Iraq. Mesopo Environ J.(4)1:52-61

40. Hassan FM, J Al-Zubaidi, and OS Youssef. Limnological Study of Diyala River, Iraq. Iraqi J Agric Sci. 2018;(3):452-462.

41. Hassan F.M, N.A.J AL-Zubaidi, AlWAA Dulaimi.2013. An ecological assessment for Tigris River within Baghdad , Iraq. J Babelon Univ.:26-39

42. Hassan M F .2004. Limnological features of Diwanyia River, Iraq. Um-Salama Sci. J Um Salama for Science1(1),:119-124

43. Hussain A.A. 2009.Monthly Changes of Some Physiochemical Parameters for Tigris River- Baghdad between 2002-2003 /(In Arabic). J Eng Technol.pp:64-70

44. Ismail AM. 1989. A Comparative Environmental Study Between The Artificial Lake Baghdad Tourist Island And The Tigris River In Baghdad. Master Thesis, Faculty of
Education Ibn al-Haytham, University of Baghdad, pp:112.University of Baghdad 45. Japan International Cooperation Agency. Profile On Environmental And Social Considerations In Iraq. 2014; March. pp:156.

46. Johnson RL. 2013. Stream Flow. Water Qual with Vernier. pp: 1-12.

47. Kafilzadeh F. 2015. Distribution and Sources of Polycyclic Aromatic Hydrocarbons in Water and Sediments of the Soltan Abad River, Iran. Egypt J Aquat Res.pp:1-5.

48. Karaer F, and A Küçükballi. 2006. Monitoring of water quality and assessment of organic pollution load in the Nilüfer stream, Turkey. Environ Monit Assess.;114(1-3):391417

49. Lind OT. 1979. Handbook Of Common Methods In Limnology. pp:199

50. Liu Y, B Beckingham, H Ruegner, Z Li, L Ma, and M Schwientek. 2013. Comparison of sedimentary PAHs in the rivers of ammer (Germany) and liangtan (China): Differences between early-and newly-industrialized countries. Environ Sci Technol. 47(2):701-709 51. Lomniczi I, A Boemo, and H Musso. 2007. Location and characterisation of pollution sites by principal component analysis of trace contaminants in a slightly polluted seasonal river: a case study of the Arenales River (Salta, Argentina). 33(4)pp:479-486.

52. Luminiţa L, T G Marian, L Boicenco, and D Vasiliu. 2012. Total organic carbon (TOC) of the surface layer sediments covering the seafloor of The Romanian Black Sea Coast. Geo-Eco-Marina.pp:121-132.

53. Mastran TA, AM Dietrich, DL Gallagher, and TJ Grizzard. 1994. Distribution of polyaromatic hydrocarbons boating activity. Science. 28(11)pp:2353-2366

54. Mathur P, Agarwal S, and M Nag. 2008. Assessment of physico-chemical Characteristics and Suggested Restoration Measures for Pushkar Lake, Ajmer Rajasthan (India).pp:1518-1529

55. Maulood, BK, HA Al-Saady, and HAS Aldhami. 1990. Practical Environment and Pollution. Ministry Of Higher Education and Scientific Research University/Al-Hikmaa House pp: 40

56. Mayer B, JB Shanley, SW Bailey, and MJ Mitchell. 2010. Identifying sources of stream water sulfate after a summer drought in the 
Sleepers River watershed (Vermont, USA) using hydrological, chemical, and isotopic techniques. Appl Geochemistry. 25(5):747754

57. Mayer X, J Ruprecht, and M bari. 2005. Stream Salinity Status And Trends In SouthWest Western Australia. pp: 188.

58. McGrath TE, JB Wooten, W G Chan, and MR Hajaligol. 2007. Formation of polycyclic aromatic hydrocarbons from tobacco: The link between low temperature residual solid (char) and PAH formation. Food Chem Toxicol. 45(6)pp:1039-1050

59. Miller JS, and D Olejnik. 2001. Photolysis of polycyclic aromatic hydrocarbons in water. Water Res. 35 (1):233-243

60. Mitsch WJ, and J Gosselink. WETLANDS. 3rd ed. New York: John Wiley \& Sons; 2000. pp:920

61. Mohammed A.B, M.M.S Taee, and F.M Hassan. 2009. The Study Of Some PAHs Compounds In Euphrates River Sediment From Al-Hindiya Barrage to Al- Kifil City Babylon, Iraq.pp: 216-230.

62. Mohammed Z.b, M.m Hazaa, and S Ali. 2015. Evaluation of the Tigris River Water Quality for Domestic and Irrigation Uses Near Drinking Water. pp:36-41

63. Moore R, G Richards, and A Story. 2008. Electrical conductivity as an indicator of water chemistry and hydrologic process. Streamline Watershed Manag Bull 11(2):25-29

64. Nashaat M.R. 2010. Impact of Al-Durah Power Plant Effluents on Physical Chemical and Invertebrates Biodiversity in Tigris River Southern Baghdad. ph.D Dissertation. Department of Biology, College of Science,University of Baghdad,pp:183.

65. Niu L, H Cai, PHAJM Van Gelder, P Luo, F Liu, and Q Yang. 2018. Dynamics of polycyclic aromatic hydrocarbons (PAHs) in water column of Pearl River estuary (China): Seasonal pattern, environmental fate and source implication. Appl Geochemistry. 90(July 2017)pp:39-49

66. Perera PACT, $\mathrm{T} V$ Sundarabarathy, $\mathrm{T}$ Sivananthawerl, and U Edirisinghe. 2014. Seasonal variation of water quality parameters in different geomorphic channels of the upper MalwathuOya in Anuradhapura , Sri Lanka.25(2)pp:158-170
67. Perra G, M Renzi, C Guerranti, and S E Focardi. 2009. Polycyclic Aromatic Hydrocarbons Pollution in Sediments: Distribution and Sources in a Lagoon System (Orbetello, Central Italy). Transitional Waters Bull.pp: 29-44.

68. Puttaiah ET, Æ CÆS. 2006. Ecological Characteristics of Vrishabhavathy River in Bangalore (India).pp:1217-1222

69. Qiu YW, G Zhang, GQ Liu, LL Guo, XD $\mathrm{Li}$, and O Wai. 2009. Polycyclic Aromatic Hydrocarbons (PAHs) in the Water Column and Sediment Core of Deep Bay, South China. Estuar Coast Shelf Sci. 83(1)pp:60-66

70. Rahi KA, T Halihan. 2018. Salinity evolution of the Tigris River. Reg Environ Chang;18(7):2117-2127

71. Roger B.B, A.D Eaton, and E.W Rice. 2017. Standard Methods for the Examination of Water and Wastewater. 23rd Edition. $23^{\text {rd }}$ Edition.pp:1550.

72. Sabri AW, Moulood BK, and Sulaiman NI. Limnological Studies on River Tigris: Some Physical and Chemical Characters. Biol Sci Res. 1989;pp:565-579

73. Salman JM, ASN Al-Azawey, and FM Hassan. 2014. The study of pollution of PAHs (Polycyclic Aromatic Hydrocarbons) in AlHilla River, Iraq by Using Bio indicator Freshwater Crab (Sesarma boulengeri Calman). J Life Sci; 8(4)pp:351-357

74. Salman J.M, F.M Hassan. and M Bayaa. 2017. Practicle_Methods in Environmental and Pollution Laboratory.pp:144

75. Santschi PH, BJ Presley, and TL Wade. 2001. Historical Contamination of PAHs , PCBs , DDTs, and Heavy Metals in Mississippi River Delta, Galveston Bay and Tampa Bay sediment cores. Marine Environmental Research. pp:51-79.

76. Sims J, and A Sharpley. 2005. Phosphorus, agriculture and the environment Illustrate. Virginia Cooperative ExtensionPublisher by American Society of Agronomy-Crop Science Society of America-Soil Science Society of America.: 1121

77. Talib A.H, F.M Hassan, and W.A Sadoon. 2014. An Environmental study on phytoplankton (diatoms) in Al- Yusifiya River, Iraq (in Arabic). J Baghdad Sci. 3:1301- 1309 78. Tehrani GM, R Hashim, AH Sulaiman, BT Sany, A Salleh, and RK Jazani. 2013. 
Distribution of total petroleum hydrocarbons and polycyclic aromatic hydrocarbons in Musa Bay sediments (Northwest of the Persian Gulf). Environ Prot Eng. 39(1)pp:115-128 79. Vrana, B, A Pasch, and P Popp. 2001. Polycyclic aromatic hydrocarbons concentrations and patterns in sediments and surface water of Mansfed Region, Saxony. Anhalt, Germany pub. Int Program ChemSaf. J. Environ. Monitor., 3(6), pp:602-609 80. Wetzel Rg, Ge Likens. 2000. Limnological Analyses. 3rd Ed. P: 430.

81. Wetzel RG. Limnology Lake and River Ecosystems Estimates of the Nitrogen in Various Compartments in Lake Wingra, Wisconsin, Midsummef 3rd ed. 2001. ACADEMIC PRESS
82. WHO (World Health Organization). Guidelines for Drinking-Water Quality. 1998. $2^{\text {nd }}$ ed.pp:203

83. Xu J, Y Yu, P Wang, W Guo, S Dai, and $\mathrm{H}$ Sun. 2007. Polycyclic aromatic hydrocarbons in the surface sediments from Yellow River, China. Chemosphere. 67 (7):1408-1414.

84. Zheng B, L Wang, K Lei, and B Nan. 2016. Distribution And Ecological Risk Assessment of Polycyclic Aromatic Hydrocarbons in Water, Suspended Particulate Matter and Sediment From Da Aliao River Estuary and The Adjacent Area, China. Chemosphere.pp:91-100

85. Zhu L, B Chen, J Wang, and H Shen. 2004. Pollution survey of Polycyclic Aromatic Hydrocarbons in Surface Water of Hangzhou, China. Chemosphere. pp:1085-109 